\title{
Using Jazz Chants to Increase Vocabulary Power among ESL Young Learners
}

\author{
Perbindar Kaur Pajan Singh1, Harwati Hashim ${ }^{2 *}$ \\ ${ }^{1}$ SK Seri Kelebang Chemor, Perak, Malaysia \\ ${ }^{2}$ Faculty of Education, Universiti Kebangsaan Malaysia, Bandar Baru Bangi, Malaysia \\ Email: ^harwati@ukm.edu.my
}

How to cite this paper: Singh, P. K. P., \& Hashim, H. (2020). Using Jazz Chants to Increase Vocabulary Power among ESL Young Learners. Creative Education, 11, 262-274.

https://doi.org/10.4236/ce.2020.113020

Received: February 16, 2020

Accepted: March 13, 2020

Published: March 16, 2020

Copyright (c) 2020 by author(s) and Scientific Research Publishing Inc. This work is licensed under the Creative Commons Attribution International License (CC BY 4.0).

http://creativecommons.org/licenses/by/4.0/ (c) (i) Open Access

\begin{abstract}
The foundation of learning starts for children from pre-school and progresses to young learners in school. They come from various backgrounds with abilities to use home languages and mother tongue. However, their exposure to English Language is very limited due to the importance of this language is neglected as it is seen as impossible to master. Therefore, this paper investigates the effects of jazz chants approach to teach English Language to $30 \mathrm{pu}-$ pils who are 10-year-old that have low proficiency level in a primary school located in a state in Malaysia. To improve teacher support and student involvement, it is crucial to have suitable strategies in educational contexts that would be able to develop a positive attitude among the pupils and improve their academic performance in English Language. The objective of this paper is to propose language learning strategies for low performance ESL pupils. It will highlight a direction which might improve the second language learning pedagogy in classrooms. Data was collected through pre-test and post-test, and satisfaction questionnaire which was given to the pupils (purposive sampling). The findings showed a marked increase in scores involving 15 students who achieved $100 \%$ scores. As a conclusion, they had motivating fun learning experience while they progressed in their learning activities.
\end{abstract}

\section{Keywords}

Jazz Chants, English a Second Language, Young Learners, Vocabulary

\section{Introduction}

According to Howe \& Strauss (2000), individuals who took birth in the late 1990's to mid-2010 are known as Generation Z who is digital savvy. Dauksevicuite (2016) claimed that this generation of individuals is pioneers who were 
born into a world globally connected by internet. They dislike waiting for a response, demand instant information and quick communication. Rothman (2016) mentioned that in some studies it was illustrated that the brains of Generation Zs have changed structurally compared to those of earlier generations. Rothman (2016) adds that this is due to the external environment and the way the brains responded to it. He further supports by stating that the brains of Generation $\mathrm{Z}$ have transformed to visual imaginary whereby the part of the brain which is responsible of visual ability has become more developed. As a result, it made visual forms of learning to be more effective. It is crucial to understand how these pupils think, what is their concern about and how they would like to be engaged. They are exposed to a variety of electronic medias with their six second patterns of imaging which then changes the brain to expect information to be delivered in short and rapid bursts as discussed by James Webb (2017) in the Generation Alpha White Paper on Information Technology.

One such study was conducted in Malaysia by Hashim and Yunus (2012) which resulted in a positive outcome of the use of TELL ME MORE courseware tool for ESL educators at a polytechnic in Melaka. Another study utilized the use of mobile social media learning and social participation roles (Norman, Nordin, Din, Ally \& Dogan, 2015) and mobile game-based learning (Zakaria, Zaini, Hamdan \& Norman, 2018). The same approaches could be applied to primary school students learning of English by introducing varied levels of exercises in constructing simple sentences.

Unison also exists among educators whereby it is highlighted that the attention span of the earlier generations as longer compared to the present $\mathrm{Z}$ generation. The attention span of $Z$ generation is almost seven to ten minutes for an average student in a classroom. Whereas it is eight seconds online and it is noted that as time progresses it gets even shorter (Rothman, 2016). Some negative situations tend to set in if young kids are exposed to a variety of languages which are not similar from their home language or their mother-tongue (Yadava, 2007). As a result, students stay away from attending school and their attendance start decreasing. Other than that, some students encounter low academic performance and there are cases of repeat classes too due to students having a high rate of failures in their studies.

Yadava (2007) also stated that observing and noting this type of learning environment highlights the need in having creative English Language lessons. Teachers may engage favorable teaching techniques that are favorable to students which will guide them to understand and learn well the given knowledge. Teachers understanding of the student's characteristics together with activities students enjoy will ensure complete learning takes place in the classroom setting. In order to cater to the needs of Generation Z, teachers who teach English Language in schools need to upgrade themselves to create interesting well-planned lessons. The purpose is to entice generation $\mathrm{Z}$ students' concentration, fulfill their expectations, encourage and motivate them to be engaged in learning Eng- 
lish. The lessons will then be able to also encourage and motivate the students to be responsible in their learning.

It has been found that there is a variety of methods that can be applied in teaching English vocabularies to students. In this study, Jazz Chant has been adopted to investigate its function in language learning. It is divided into two main areas which are topic chants and grammar chants. Topic chants focuses on wide themes such as animals, occupations, food and clothing. Whereas, grammar chants focus on usage of grammatical in English texts focusing in nouns, pronouns and other grammar items. The theme of food is chosen for this research as it appeals to the 10-year-old students. The objective of this research is to examine the effectiveness of the use of Jazz Chants to develop students' ability to recall and remember words with correct spelling.

\section{Literature Review}

\subsection{Jazz Chant and Vocabulary Learning}

A Jazz Chant is a rhythmic presentation of natural language. It is linking of the rhythms of natural spoken American English to the rhythms of traditional American jazz as stated (Graham, 2006). Jazz Chants are very easy and simple to follow. The teachers and pupils do not need to have musical background to carry out activity. Pupils need to work with the sound system of English, particularly for developing their listening skill to the intonation patterns, rhythm and correct stress of the language. According to Kung (2013), the use of Jazz Chants provides features of stress and intonation, so the involvement of relative levels of stress and pitch within syllables, words, phrases and longer stretches of speech can be produced more effectively. Chanting is an enjoyable positive activity with the usage of multiple repetition or words and phrases that can be carried out added by body movements without struggling with repetitive boring drills. Teachers need to be creative in selecting the suitable, exciting movements and presentation which are pupils friendly. It also aids memorization and reinforce grammar which will ensure that pupils stay motivated.

It was pointed out by Mata, Monteiro and Peixoto (2012), that negative attitude might affect students' motivation and engagement in academic work. Besides building positive environment, pupils can practice the patterns of everyday conversation too. This proves the role English teachers are crucial to engage with pupils in attaining and enriching their vocabularies.

There are pros and cons on the use of information communication technology in teaching. According to the study by Yunus, Nordin, Salehi, Sun \& Embi (2013) the advantages outshines the disadvantages which are attracting students to focus in gaining knowledge, guiding students in their learning process, empowering students in accumulating their vocabularies and attaining worthwhile learning.

To justify this point based on Rahimpour (2004) stated that there are three early meaningful speech stages of young learners who learn language which are 
naming and holophrastic, telegraphic and morphemic transformational. At every stage, young learners improve their vocabulary and language ability. They need somebody else to develop their vocabulary, in the stage of naming and holophrastic; they need their parents to teach them the name of something, such as the name of things in their surroundings. Then in the stage of telegraphic; they use a single word to express a thought for which adults usually use a whole sentence. When they are saying "puppet" could mean: "I want my puppet", "Here is my puppet", "Where is my puppet?" or "Hello puppet". The next stage is morphemic-transformational; they need their parents and teacher to teach them about how to arrange words into sentence and how to arrange sentences into paragraph.

A good vocabulary range makes young learners enhance their reading comprehension and writing ability. Here it proves the importance of gaining a vast range of vocabularies in a child's life and the role of a teacher is vital. The most important moments to begin to master another language is as a child (Sarem \& Hamidi, 2012). This reveals that acquiring a second or foreign language is best done when an individual is young and has not reached puberty. This will encourage the child to learn to speak it naturally. A learner who is a child can easily receive new information because the learner is in the phase of learning.

\subsection{Factors Affecting Learning of English Language in Malaysia}

Studies have shown that learners' language learning apprehensions are born from within the learners themselves, school practices and their social too besides cultural influences by putting them psychologically and linguistically secluded from the English language (Ismail, 2008; Aziz \& Hashima, 2007). It is also proven that the causes of the problem are encouraged by the education system in Malaysia which highly promotes the focus of national based assessment which then produces students who are unable to perform independently. This opinion is supported by (Koo, 2008). Other than that, Kaur (2006) adds on to mention that pupils prefer to take the role of empty vessels and assume in their minds that their educators are responsible to give them knowledge which they need to acquire in their life. Automatically this does not encourage independent language learning. Correspondingly, Pandian (2002) mentions that due to the focus on examinations in the school system, pupils fully rely on their educators in their learning journey. Some authors state that in local higher learning institutions, importance is still placed on attaining excellent results in exams (Siong, Azman, \& Lie, 2010; Koo, 2008).

The focus is still placed on memorizing and regurgitating. Here, it can be seen clearly that assessment of language learning strategies in teaching English language in this country needs to be reassessed. It can be suggested that out-of-classroom practices in learning can be incorporated into the learning as well as on sociocultural influences in English learning (Kaur, 2006). This is to encourage the interpretation of pupils' reading, learning styles and to nurture learning among pupils (Noor, 2006; Mustaffa, 2006). As such, it reflects clearly 
that English teachers should take proactive steps to select appropriate chants for their pupils.

In order to learn a language, it is usually learned by firstly listening, followed by speaking and then progressing to learning to read, and finally to write. In this case, learners should be equipped with receptive language skills first before productive language skills. They gained access to language input through receptive skills which were listening and reading. Based on the information stated above, this study attempted to use jazz chants as an approach to improve about improving students' vocabulary mastery on the topic of food based on their national curriculum year 4 textbook.

\section{Methodology}

\subsection{Participants}

In this study, 30 students comprised of 20 Malay boys and 10 Malay girls. These pupils were from families who were not fluent in English Language and some of them had the influence of grandparents' mother tongue. They had low proficiency level in the English language which affected their listening, speaking, reading and writing abilities. As the usage of the language was minimal, pupils lacked practice to encourage them to use the learned words after each lesson in class. As a result, Jazz Chants were used in order to encourage pupils to recall and remember words clearly after their lessons.

\subsection{Research Design and Procedure}

Pupils' mastery of correct spellings of food vocabulary and their motivation towards learning was collected by the researcher. Due to cases where pupils failed to always recall the correct spelling of words due to the influence of Bahasa Malaysia which had words that had similar pronunciation, for example donut (Bahasa Malaysia) and doughnut (English), this topic was selected. Qualitative and quantitative data collection was applied in this research. This research was designed to follow the Cyclical model, as described by Kemmis and McTaggart (1982) in Figure 1.

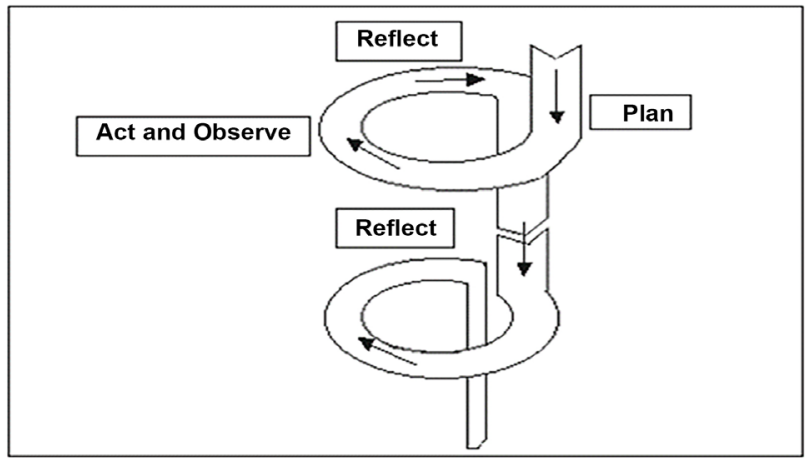

Figure 1. Cyclical model, as described by Kemmis and McTaggart (1982). 
The first step that was undertaken was to carry out a pretest, to understand the pupils' mastery in the vocabulary, focusing on correct spelling. Learners were asked to write words to match to given pictures. Evaluations were carried out. Then by referring to the cyclical model, the researchers introduced the Jazz Chant activity to pupils. First the activity was carried out in groups of five. As the students became more confident, they presented the Jazz Chant individually. After the activity was carried out, the researcher observed the pupils' achievements and evaluated them. Next, pupils were given a post-test to see their progress in their spelling.

\subsection{Instruments}

\subsubsection{Pre-Test and Post-Test}

In the pre-test and post-test, 20 words were selected according to the pupils' textbook. Every word in the prepared list was marked. One mark was awarded for words with correct spelling and zero mark for incorrectly spelled words. Each student's written response was tabulated, and total scores were given for every student. The differences in scores were translated as in Table 1. Below were the nouns that were tested. These words relate to the topic food, which also have almost similar pronunciations in English Language and Bahasa Malaysia. The pre-test and post-test were carried out on 30 selected participants.

\subsubsection{Questionnaire}

A questionnaire was used to obtain students opinion and motivation. Students responded to 14 items which are based on motivation and confidence. The instrument used in this study is to investigate pupils' participation on the use of jazz chant as a Language Learning Strategy. The adapted version of Language Learning Strategy Used Questionnaire consists of pre-test was given before Jazz Chants were introduced and the similar questionnaire was handed out as post-test instrument. A 5-point Likert scale ranging from 1-5 was used in this questionnaire. A 5-point Likert scale is as the following 1) Strongly disagree, 2) Disagree, 3) Neither agree nor disagree, 4) Agree, 5) Strongly agree. A comparison was made between both sets of responses to gauge the effectiveness of Jazz Chants. Similarly, the questionnaire was distributed to the chosen participants. Every student was guided to understand each statement and they carefully selected well their response to give feedback regarding Jazz Chants to increase vocabulary power among the ESL students.

Table 1. Word list of vocabularies tested in the research.

\begin{tabular}{ccccc}
\hline & \multicolumn{5}{c}{ Word List } \\
\hline nuggets & jelly & cake & curry puff & nuggets \\
\hline doughnut & soup & curry & pie & doughnut \\
sandwich & apple & pie & sauce & sandwich \\
sausage & bun & chocolate & chilly & sausage \\
strawberry & peach & prune & avocado & strawberry \\
\hline
\end{tabular}




\section{Findings and Discussion}

\subsection{The Effect of Jazz Chants in Student's Performance}

Before carrying out the Jazz Chant activity a pre-test was carried out among the mixed abilities target students who have different levels of proficiency in English Language and have different speeds of learning too. First students were given a spelling evaluation test which consisted of 20 words. They were requested to write down each word as it was uttered by the teacher. The topic selected was based on various types of food. Attention was also given to some of the food types which had similar sound in English and Bahasa Malaysia but the spelling was different, for example curry puff (English) and karipap (Bahasa Melayu).

A post-test was administered after the implementation. As the pre-test was completed, it was found that the maximum total words spelled correctly were 15 and it was scored by only one pupil. It was also found that there were zero scores too. After introducing and carrying out the Jazz Chants activity among the students, a post-test was carried out to determine the success of the activity among the involved students. When the post-test was undertaken, a marked increase in scores was detected. Whereby, 15 students were able to get $100 \%$ scores. This meant that they were able to spell all the 20 words in the word list correctly. A marked improvement was seen in all the students. Each of the students was able to increase the level of achievement. Results portrayed positive achievement in the mastery of vocabulary as presented in the table below.

The results of the pre-test and post-test in Table 2 illustrates that all students performed very well after they were introduced to learning vocabularies through Jazz Chant method. Every student showed an increased level in the post-test. As the results were compared between pre-test and post-test evaluation, it was found that that there was at least a minimum difference in scores starting from 3 words correctly spelled to a maximum of 20 words. This meant that $75 \%$ of the 30 students were able to score $100 \%$ correct results. It proves that 15 students managed to learn the correct spelling of the introduced words. Then, they were able to recall and write the tested words using correct spelling in the post-test. It was also noted that a student who scored zero in the pre-test was able to show positive learning by attaining a score of 20 marks in the post-test.

\subsection{Students' Perception towards the Use of Jazz Chants}

The 30 students attempted well in their survey questionnaires. The survey results showed that more than $50 \%$ of the pupils love to carry out the Jazz Chants activity and it also ensured them to feel happy. Most of them felt motivated in learning vocabularies through Jazz Chants. Significantly, during their acting and presentation sessions, gave a big boost in their self-esteem and confidence. It was noted that $70 \%$ of the students showed willingness to share their learning experience with their fellow friends. This element is very positive and crucial as it allows a success in collaborative activities among the mixed abilities students. The findings also revealed that the students strongly agree that they want to learn new English words through Jazz Chants. 
Table 2. Pre-test and post-test results of jazz chants among students.

\begin{tabular}{|c|c|c|c|}
\hline Participants & Pre-test & Post-test & Difference in Scores \\
\hline Student 1 & 10 & 20 & 10 \\
\hline Student 2 & 7 & 19 & 12 \\
\hline Student 3 & 7 & 20 & 13 \\
\hline Student 4 & 10 & 20 & 10 \\
\hline Student 5 & 15 & 20 & 5 \\
\hline Student 6 & 0 & 20 & 20 \\
\hline Student 7 & 12 & 20 & 8 \\
\hline Student 8 & 14 & 17 & 3 \\
\hline Student 9 & 7 & 20 & 13 \\
\hline Student 10 & 7 & 14 & 7 \\
\hline Student 11 & 2 & 5 & 3 \\
\hline Student 12 & 11 & 20 & 9 \\
\hline Student 13 & 8 & 20 & 12 \\
\hline Student 14 & 9 & 18 & 9 \\
\hline Student 15 & 8 & 20 & 12 \\
\hline Student 16 & 10 & 20 & 10 \\
\hline Student 17 & 6 & 20 & 14 \\
\hline Student 18 & 5 & 14 & 9 \\
\hline Student 19 & 7 & 19 & 12 \\
\hline Student 20 & 7 & 19 & 12 \\
\hline Student 21 & 3 & 13 & 10 \\
\hline Student 22 & 6 & 16 & 10 \\
\hline Student 23 & 13 & 20 & 7 \\
\hline Student 24 & 4 & 19 & 15 \\
\hline Student 25 & 8 & 19 & 11 \\
\hline Student 26 & 9 & 18 & 9 \\
\hline Student 27 & 12 & 20 & 8 \\
\hline Student 28 & 7 & 12 & 5 \\
\hline Student 29 & 8 & 19 & 11 \\
\hline Student 30 & 3 & 20 & 17 \\
\hline
\end{tabular}

Table 3 presents each statement in the questionnaire that is given to the pupils that allows them to select one of five choices presented in the Likert Scale to express their perception to learning new English vocabulary and the effectiveness of Jazz Chants. Interpretation of mean score was used to determine the frequency of language learning strategies. Data are reported using frequency and percentages. 
Table 3. Questionnaire (Percentage and frequency).

\begin{tabular}{|c|c|c|c|c|c|}
\hline Statement & $\begin{array}{c}\text { Strongly Disagree } \\
\%(\mathrm{~N})\end{array}$ & $\begin{array}{c}\text { Disagree } \\
\%(\mathrm{~N})\end{array}$ & $\begin{array}{l}\text { Neither Agree Nor } \\
\text { Disagree \% (N) }\end{array}$ & $\begin{array}{l}\text { Agree } \\
\%(\mathrm{~N})\end{array}$ & $\begin{array}{c}\text { Strongly Agree } \\
\%(\mathrm{~N})\end{array}$ \\
\hline I love Jazz Chants & (0) & (0) & $6.67(2)$ & $33.33(10)$ & $60.00(18)$ \\
\hline Jazz Chants help me to be happy & (0) & (0) & $6.67(2)$ & $30.00(9)$ & $63.33(19)$ \\
\hline $\begin{array}{l}\text { Jazz Chants make me feel } \\
\text { motivated to learn English }\end{array}$ & (0) & (0) & $3.33(1)$ & $40.00(12)$ & $56.67(17)$ \\
\hline $\begin{array}{l}\text { Jazz Chants allow me to recall } \\
\text { easily English words }\end{array}$ & (0) & $3.33(1)$ & $0.00(0)$ & $50.00(15)$ & $46.67(14)$ \\
\hline $\begin{array}{l}\text { Matching the sound of a word that I } \\
\text { know to the food is easy for me }\end{array}$ & (0) & (0) & $6.67(2)$ & $36.67(11)$ & $56.67(17)$ \\
\hline $\begin{array}{l}\text { I have the confidence to construct } \\
\text { sentences correctly using the } \\
\text { English words. }\end{array}$ & (0) & (0) & $33.33(10)$ & $56.67(17)$ & $10.00(3)$ \\
\hline $\begin{array}{l}\text { I enjoy chanting words to } \\
\text { remember correct spelling }\end{array}$ & (0) & $3.33(1)$ & $3.33(1)$ & $50.00(15)$ & $43.33(13)$ \\
\hline $\begin{array}{l}\text { Chanting several times helps } \\
\text { me to revise new words }\end{array}$ & (0) & (0) & $6.67(2)$ & $56.67(17)$ & $36.67(11)$ \\
\hline $\begin{array}{l}\text { Acting out English words } \\
\text { makes me relaxed physically }\end{array}$ & (0) & (0) & $20.00(6)$ & $63.33(19)$ & $16.67(5)$ \\
\hline $\begin{array}{l}\text { I have a list of the correct spelling } \\
\text { of words that I learn every day. }\end{array}$ & (0) & (0) & $13.33(4)$ & $43.33(13)$ & $43.33(13)$ \\
\hline $\begin{array}{l}\text { I feel great when I share with my } \\
\text { friends the words learned }\end{array}$ & (0) & (0) & $30.00(9)$ & $30.00(9)$ & $40.00(12)$ \\
\hline I can group words & (0) & (0) & $16.67(5)$ & $43.33(13)$ & $40.00(12)$ \\
\hline $\begin{array}{l}\text { It is easy for me to recall the } \\
\text { correct spelling of learned words }\end{array}$ & (0) & (0) & $13.33(4)$ & $46.67(14)$ & $40.00(12)$ \\
\hline $\begin{array}{l}\text { I can match pictures to the } \\
\text { correct spelling }\end{array}$ & $(0)$ & (0) & $3.33(1)$ & $43.33(13)$ & $53.33(16)$ \\
\hline $\begin{array}{l}\text { I want to learn more new } \\
\text { English words }\end{array}$ & (0) & (0) & $3.33(1)$ & $10.00(3)$ & $86.67(26)$ \\
\hline
\end{tabular}

The statements presented to the pupils in the questionnaire are associated with the level of their comfort towards learning and using Jazz Chants to master new English words. Overall, pupils show positive response by stating clearly that they love Jazz Chants. These pupils add further to state that through the experience of Jazz Chants the ability to sustain a certain level of joy and happiness within them was achieved. Only a minority, 2 individuals, were unable to make a concrete stand on these points. As the majority, around 99\%, of the pupils gained confidence, their level of motivation raised to a higher level. Through the gained confidence and motivation towards learning the English language as a result of using Jazz Chants, pupils could remember words with the correct spelling too. More than $90 \%$ of pupils support the idea that the ability to match pictures to the words with accurate spelling became better. The results show that generally, $70 \%$ of them agree that sharing newly learned words with their friends 
made them good. Furthermore, most of the pupils showed that they were comfortable to attempt forming sentences using learned English words. However, 10 pupils were still reserved and unsure of their potential in making sentences using English vocabularies. The action of chanting encouraged pupils and supported almost $90 \%$ of them to revise new words. Besides, it helped the pupils to feel relaxed too while they were chanting and acting out the words. At least $80 \%$ of them successfully managed to compile word lists with correct spelling which they can continuously refer to. It also shows the positive perception of pupils to learn new English words in the future.

\subsection{Discussion}

Results from the difference in achievements among high and low performing students in the pre-test and post-test show that there is increase in their level of mastering correct spelling. It showed that the high performing students captured much better results and the low performing did make a small change in their progress. According to Bancroft (1985) it is worth encouraging language teachers to employ music and Jazz Chants for better and more effective L2 learning results among students. This proves that to enable the pupils to enrich their vocabularies they should be exposed to regular Jazz Chants activities. Overall results in the post-test have reflected that there were marked improvement in all the pupils' achievement. Results in the pre-test which were nil could skyrocket to $100 \%$ in the post-test and the slow learners were also able to leave a marked improvement. This shows that with the introduction of Jazz Chant to the students, their mastery in spelling words increased significantly and affected positively for the ability of low performing pupils. Apart from that, Jazz Chants techniques can be used to gain some benefits of increasing motivation in learning process (Artini, 2019).

In terms of students' perception towards the use of Jazz Chants, it was noted that there was a pupil who disagreed with the statement Jazz Chants allow me to recall easily English words and another disagreement was about the statement $I$ enjoy chanting words to remember correct spelling. Observing these facts, it was then recommended by the researcher that adding an approach could help to overcome these findings and solve the matter. It is recommended that a visualization and personalization activity to be added to the jazz chant learning for selected students.

Nation, Adams, Bowyer-Crane, \& Snowling, (1999) stated that the technique of visualization in learning has been highly regarded in literature. As an example, in a study conducted in Thailand, the students were able to remember vocabularies more easily with the aid of electronic images (Vungthong, Djonov, \& Torr, 2017). This is because images can help to reinforce the learning of a new word due to an added sensory element (other than the spelling and/or sound of the word) which is now made available to be accepted by the brain. The act of visualizing can be from an image of a brinjal and the word brinjal written beside the image to personalizing visualization. As an example, when the word pre- 
sumptuous is verbally introduced and then explained to a class of students along with its spelling. Examples of scenarios that depict the definition of the word can be introduced to the students to encourage them to visualize that situation associated with the word in order to remember the word more vividly.

\subsection{Conclusion}

From the findings, it can be concluded that generally Jazz Chants are able to guide students to master the acquisition of vocabularies in their learning of English Language. In this study, a large number of students are positive in participating actively in the Jazz Chant activities and they attain high level of motivation to progress further in learning new words. Even though there are a small number of students who are skeptical, added activities can be formulated to encourage them to happily take part in Jazz Chant practices. The added activities can range from visualization to personalizing visualization. Besides, it is proven among the selected students that Jazz Chants activity has guided them tremendously well in upgrading their English Language. Although it was accepted by majority of them, there were some students who have highlighted the need for extra attention from the researcher. It was a good finding and could help to encourage for further research on this fact to further develop on Jazz Chant. It can also be suggested here that for students who are highly motivated to learn vocabularies through Jazz Chants can then be exposed further to acquiring the skill of writing sentences using the Jazz Chants method. It is highly recommended that through the implementation of Jazz Chants activities, confidence can be further nurtured in students to remember spelling of phrases. The fast-paced technological learning environment has made it more challenging to encourage generation $\mathrm{Z}$ students to read and memorize English words. However, there are instances where technology can support students learning of the language.

\section{Acknowledgements}

We thank the Faculty of Education at Universiti Kebangsaan Malaysia for providing adequate resources and guidance in order to successfully accomplish this study.

\section{Conflicts of Interest}

The authors declare no conflicts of interest regarding the publication of this paper.

\section{References}

Artini, N. N. S. (2019). A Collaborative Study in Improving Competency in Speaking Skill by Using "Jazz Chant Technique" of the Students Grade Five at SD Negeri 2 Banjar Tegal Singaraja. Yavana Bhāshā: Journal of English Language Education, 1. https://doi.org/10.25078/yb.v1i2.728

Aziz, N. H. A., \& Hashima, N. (2007). ESL Students' Perspectives on Language Anxiety. 
Doctoral Dissertation, Malaysia: Universiti Putra Malaysia.

Bancroft, W. J. (1985). Music Therapy and Education. Journal of the Society for Accelerative Learning and Teaching, 10, 3-16.

Dauksevicuite, I. (2016). Unlocking the Full Potential of Digital Native Learners. New York: McGraw Hill Education.

Graham, C. (2006). Teaching Jazz Chants to Young Learners. Washington DC: English Language Program.

Hashim, H., \& Yunus, M. M. (2012). Tell Me More: Issues and Challenges. Advances in Language and Literary Studies, 3, 136-146. https://doi.org/10.7575/aiac.alls.v.3n.2p.136

Howe, N., \& Strauss, W. (2000). Millennials Rising: The Next Great Generation. Vintage.

Ismail, R. (2008). Factors Affecting Less Proficient ESL learners' Use of Strategies for Language and Content Area Learning. Doctoral Dissertation, Malaysia: Universiti Putra Malaysia.

James, W. (2017). Generation Alpha White Paper on Information Technology. Canyon, TX: West Texas A\&M University.

Kaur, N. (2006). Non-Autonomy and Low-English Proficiency among Malaysian Students: Insights from Multiple Perspectives. Doctoral Dissertation, Shah Alam: Universiti Teknologi MARA.

Kemmis, S., \& McTaggart, R. (1982). The Action Research Planner. Geelong: Deakin University Press.

Koo, Y. L. (2008). Language, Culture and Literacy: Meaning-Making in Global Contexts. Bangi: Universiti Kebangsaan Malaysia.

Kung, F. W. (2013). Rhythm and Pronunciation of American English: Jazzing up EFL Teaching through Jazz Chants. The Asian EFL Journal, 70, 4-27.

Mata, M. D. L., Monteiro, V., \& Peixoto, F. (2012). Attitudes towards Mathematics: Effects of Individual, Motivational, and Social Support Factors. Journal of Child Development Research, 2012, 1-4. https://doi.org/10.1155/2012/876028

Mustaffa, R. (2006). The Effects of Culture on Students' Learning Styles. 3L: Language, Linguistics, Literature, 12, 83-94.

Nation, K., Adams, J. W., Bowyer-Crane, C. A., \& Snowling, M. J. (1999). Working Memory Deficits in Poor Comprehenders Reflect Underlying Language Impairments. Journal of Experimental Child Psychology, 73, 139-158. https://doi.org/10.1006/jecp.1999.2498

Noor, N. M. (2006). Reading Academic Text: Awareness and Experiences among University ESL Learners. GEMA Online Journal of Language Studies, 6, 65-78.

Norman, H., Nordin, N., Din, R., Ally, M., \& Dogan, H. (2015). Exploring the Roles of Social Participation in Mobile Social Media Learning: A Social Network Analysis. The International Review of Research in Open and Distributed Learning, 16, 205-224. https://doi.org/10.19173/irrodl.v16i4.2124

Pandian, A. (2002). English Language Teaching in Malaysia Today. Asia Pacific Journal of Education, 22, 35-52. https://doi.org/10.1080/0218879020220205

Rahimpour, M. (2004). Developmental Stages of Child Language. Journal of Faculty of Letter and Humanities University of Tabriz, No. 190, 57-70.

Rothman, D. (2016). A Tsunami of Learners Called Generation $Z$. http://www.mdle.net/JoumaFA Tsunami of Learners Called Generation Z.pdf

Sarem, S. N., \& Hamidi, H. (2012). A Critical Look at the Available Literature on the Appropriate Time to Start Approaching a Second/Foreign Language. Advances in English 
Linguistics, 1, 76-79.

Siong, L. K., Azman, H., \& Lie, K. Y. (2010). Investigating the Undergraduate Experience of Assessment in Higher Education. GEMA Online Journal of Language Studies, 10, 17-33.

Vungthong, S., Djonov, E., \& Torr, J. (2017). Images as a Resource for Supporting Vocabulary Learning: A Multimodal Analysis of Thai EFL Tablet Apps for Primary School Children. TESOL Quarterly, 51, 32-58. https://doi.org/10.1002/tesq.274

Yadava, Y. P. (2007). Linguistic Diversity in Nepal: Perspectives on Language Policy. Kathmandu: International Seminar on Constitutionalism and Diversity in Nepal. Centre for Nepal and Asian Studies, Tribhuvan University.

Yunus, M. M., Nordin, N., Salehi, H., Sun, C. H., \& Embi, M. A. (2013). Pros and Cons of Using IICT in Teaching ESL Reading and Writing. International Education Studies, 6, 119-130. https://doi.org/10.5539/ies.v6n7p119

Zakaria, N. Y. K., Zaini, H., Hamdan, F., \& Norman, H. (2018). Mobile Game-Based Learning for Online Assessment in Collaborative Learning. International Journal of Engineering \& Technology, 7, 80-85. 